\title{
Subclinical hypothyroidism in pregnant rats impaired learning and memory of their offspring by promoting the p75 ${ }^{\mathrm{NTR}}$ signal pathway
}

\author{
Fan Zhang, Jian Chen, Xinyue Lin, Shiqiao Peng, Xiaohui Yu, Zhongyan Shan and Weiping Teng
}

Department of Endocrinology and Metabolism, Institute of Endocrinology, Liaoning Provincial Key Laboratory of Endocrine Diseases, The First Affiliated Hospital of China Medical University, Shenyang, Liaoning, China

Correspondence should be addressed to X Yu: yuxh_1978@126.com

\begin{abstract}
Objective: Maternal hypothyroidism during pregnancy can affect the neurodevelopment of their offspring. This study aimed to investigate the effects of maternal subclinical hypothyroidism $(\mathrm{SCH})$ on spatial learning and memory, and its relationship with the apoptotic factors in cerebral cortex of the offspring.

Methods: Female adult Wistar rats were randomly divided into three groups $(n=15$ per group): control (CON) group, $\mathrm{SCH}$ group and overt hypothyroidism $(\mathrm{OH})$ group. Spatial learning and memory in the offspring were evaluated by long-term potentiation (LTP) and Morris water-maze (MWM) test. The protein expression of the p75 neurotrophin receptor $\left(\mathrm{p} 75^{\mathrm{NTR}}\right)$, phospho-c-Jun N-terminal kinase ( $\left.\mathrm{p}-\mathrm{JNK}\right)$, the pro-apoptotic protein p53 and Bax were detected by Western blotting.

Results: The Pups in the $\mathrm{SCH}$ and $\mathrm{OH}$ groups showed longer escape latencies in the MWM and decreased field-excitatory post synaptic potentials in LTP tests compared with those in the CON group. p75 ${ }^{\mathrm{NTR}}, \mathrm{p}$-JNK, p53 and Bax expression levels in the cerebral cortex increased in pups in the $\mathrm{SCH}$ and $\mathrm{OH}$ groups compared with those in the CON group. Conclusions: Maternal SCH during pregnancy may impair spatial learning and memory in the offspring and may be associated with the increased apoptosis in the cerebral cortex.
\end{abstract}

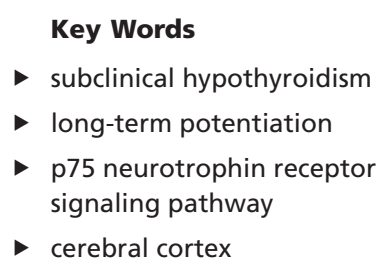

Endocrine Connections (2018) 7, 688-697

\section{Introduction}

Thyroid hormones(THs) arevital for fetal neurodevelopment. The prevalence of subclinical hypothyroidism $(\mathrm{SCH})$ in the general population is $4-10 \%$ and can reach $5 \%$ in pregnant women. Haddow et al. investigated the intelligence levels of 62 children aged 7-9 years who were born to mothers with thyroid dysfunction during early pregnancy. They found that even mild and asymptomatic hypothyroidism in pregnant women, including $\mathrm{SCH}$, could affect the development of intelligence in their offspring (1). Several experimental studies also found that maternal $\mathrm{TH}$ deficiency during pregnancy could cause irreversible brain

http://www.endocrineconnections.org https://doi.org/10.1530/EC-18-0069

C2018 The authors Published by Bioscientifica Ltd damage in the offspring, resulting in varying degrees of mental retardation, cognitive impairment and learning and memory dysfunction $(2,3,4,5)$. We previously found that decreased activation of the cAMP response element-binding protein signaling pathway in pups was related to impaired cognitive function caused by maternal SCH (6). However, the relationship between cognitive impairment due to $\mathrm{SCH}$ and the apoptosis in cerebral cortex remains unclear.

The p75 neurotrophin receptor $\left(p 75^{\mathrm{NTR}}\right)$ is an important member of the death receptor family. Although the role of the $\mathrm{p} 75^{\mathrm{NTR}}$-mediated signal transduction 
pathway in promoting apoptosis is currently unclear, the activation of the JNK signaling pathway is thought to be an important step in this process $(7,8)$. Previous studies showed that the expression of $\mathrm{p} 75^{\mathrm{NTR}}$ increased in the cerebral cortex of pups from mothers with perinatal hypothyroidism, and the pro-apoptotic protein such as p53 and Bax increased (9, 10). However, whether neuronal apoptosis induced by the p75 ${ }^{\mathrm{NTR}}$ signaling pathway exists in the offspring of pregnant $\mathrm{SCH}$ rats remains unknown.

This study aimed to determine if the $\mathrm{p} 75^{\mathrm{NTR}}$ signaling pathway was activated in the cerebral cortex in the offspring of rats with SCH during pregnancy and to investigate its role in the apoptosis of cerebral cortex.

\section{Materials and methods}

\section{Animals}

This experiment used 45 female rats (weighing 190-210 g) that had never been pregnant. All female rats were kept in the Experimental Animal Department at China Medical University under specific pathogenfree conditions, in a constant environment at $23-25^{\circ} \mathrm{C}$ and 55\% relative humidity with a 12 -h light/darkness cycle, and provided with normal feed and water. Rats were fed normally for 1 week before the experiment. All animal experiments and procedures were approved by the Animal Care and Use Committee at China Medical University, which complies with the National Institutes of Health Guide for the Care and Use of Laboratory Animals (NIH Publications No. 8023, revised 1978). The rats were randomly assigned to three groups: control group (CON, $n=15)$, overt hypothyroidism group $(\mathrm{OH}, n=15)$ and $\mathrm{SCH}$ group $(n=15)$. Rats in the $\mathrm{OH}$ and $\mathrm{SCH}$ groups were treated by intraperitoneal (i.p.) injection of $3 \%$ pentobarbital sodium $(0.1 \mathrm{~mL} / 100 \mathrm{~g})$ and underwent thyroidectomy. CON rats underwent sham thyroid surgery. After surgery, rats were kept at $34 \pm 2{ }^{\circ} \mathrm{C}$ under an electric blanket until they awoke. One month after surgery, rats in the SCH group were injected subcutaneously with L-thyroxine (L-T4, Sigma, USA) $1.0 \mu \mathrm{g} / 100 \mathrm{~g} /$ day on the back or neck. Rats in the
$\mathrm{CON}$ and $\mathrm{OH}$ groups were injected subcutaneously with physiological saline $(50 \mu \mathrm{L} / 100 \mathrm{~g} /$ day $)$ on the back or neck. Calcium lactate $(0.1 \% \mathrm{w} / \mathrm{v})$ was added to the drinking water for all rats after surgery. After 9 days of injections, all rats were mated with normal male rats (male: female $=1: 2$ ). Then, pregnant rats were placed in solitary confinement until delivery. The female rats were observed daily until they gave birth, and the delivery day was recorded as postnatal day 0 (PND0). All pups were weaned and the mothers stopped receiving subcutaneous injections on PND21. Venous blood (approximately $2 \mathrm{~mL}$ ) was collected from all pregnant rats via the inner canthus vein on the 9th day after initial subcutaneous injection of L-T4 and on PND0, to detect total thyroxine (TT4) and thyroid-stimulating hormone (TSH) levels. Six to eight pups from each group on PND7 were decapitated on ice and the cerebral cortex was removed for Western blotting. The remaining pups were raised to PND39 and subjected to the Morris watermaze (MWM) test $(n=10)$ and long-term potentiation (LTP) experiments $(n=6)$, finishing on PND44. The project timeline is described in Fig. 1.

\section{Measurements of TT4 and TSH}

Blood samples obtained from the rats were immediately centrifuged at $20,913 \boldsymbol{g}$ for $13 \mathrm{~min}$ and stored at $-80^{\circ} \mathrm{C}$ for subsequent chemiluminescence immunoassay (Immulite, Diagnostic Products Corporation, Los Angeles, CA, USA) to measure serum TT4 and TSH. The inter- and intra-assay coefficients of variation (CVs) for TT4 was $3.83-7.09 \%$ and $1.58-3.68 \%$, respectively. The inter- and intra-assay (CVs) for TSH were 1.87-5.43\% and $2.34-3.47 \%$, respectively. Based on $>95 \%$ specific binding, the limit of detection for TT4 was $1.0 \mu \mathrm{g} / \mathrm{dL}$. And the results samples below the level of detection were recorded at $1.0 \mu \mathrm{g} / \mathrm{dL}$ for statistical purposes.

\section{MWM test}

The MWM test was used to assess the spatial learning abilities of the pups in all groups. The MWM consists of a black circular swimming pool $(100 \mathrm{~cm}$ diameter, $60 \mathrm{~cm}$

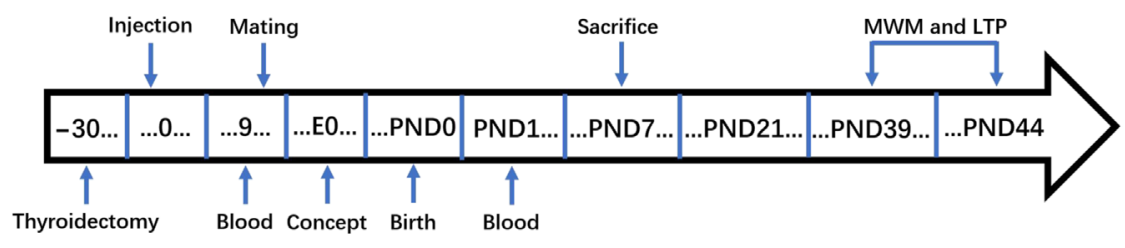

Figure 1

Schematic of experimental timeline. E0, gestational day 0; LTP, long-term potentiation; MWM, Morris Water Maze; PND, postnatal day.

(2)18 The authors Published by Bioscientifica Ltd http://www.endocrineconnections.org https://doi.org/10.1530/EC-18-0069

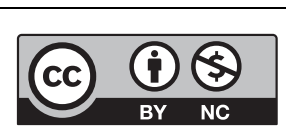

This work is licensed under a Creative Commons Attribution-NonCommercial 4.0 International License. 
deep) divided into four equal quarters (I, II, III, IV) by two straight lines. A circular platform $(10 \mathrm{~cm}$ diameter) is located $1 \mathrm{~cm}$ below the surface in the middle of quadrant IV. The rats were allowed to swim freely for $120 \mathrm{~s}$ on the first day (PND39) to adapt to the water maze and platform, and training was then started on the following day (PND40). Each pup trained four times a day, and rested for $1 \mathrm{~min}$ after each training session. The time required for the pup to climb the platform was defined as the escape latency. If the pup had not found the platform after 120 s, the escape latency was recorded as 120 s. All the pups that completed the experiment were lifted out gently, dried with a towel and then returned to their cages. The procedure was repeated for 4 days (PND40, PND41, PND42, PND43). On the sixth day, the platform was removed and the experiments performed in the previous 4 days were repeated. We recorded the number of times each pup reached the platform area and the time spent in the area for $120 \mathrm{~s}$ and assigned this as a probe trial. The escape latency for pups in each group was recorded daily. The time spent in the platform quadrant and the number of times they crossed the platform quadrant were measured in the last day's probe test.

\section{LTP induction in vivo}

We measured field-excitatory postsynaptic potentials (f-EPSPs) in the hippocampus of the pups in each group using a MED64 planar microelectrode matrix recording system (Alpha Med Science, Osaka, Japan). On PND40, the pups were decapitated on ice after anesthesia with $3 \%$ sodium pentobarbital $(30 \mathrm{mg} / \mathrm{kg}$, i.p.). Brain tissue was cut into $300-\mu \mathrm{m}$ thick slices, removed and placed into oxygenated artificial cerebrospinal fluid containing $7.25 \mathrm{~g} / \mathrm{L} \mathrm{NaCl}, 0.22 \mathrm{~g} / \mathrm{L} \mathrm{KCl}, 2.18 \mathrm{~g} / \mathrm{L} \mathrm{NaHCO}_{3}, 0.12 \mathrm{~g} / \mathrm{L}$ $\mathrm{MgSO}_{4}, 0.17 \mathrm{~g} / \mathrm{L} \mathrm{KH}_{2} \mathrm{PO}_{4}, 1.8 \mathrm{~g} / \mathrm{L}$ glucose and $0.22 \mathrm{~g} / \mathrm{L}$ $\mathrm{CaCl}_{2}(\mathrm{pH} 7.35-7.45)$. The temperature of the brain was maintained at $34 \pm 1^{\circ} \mathrm{C}$ and the flow rate of the artificial cerebrospinal fluid was $1-1.5 \mathrm{~mL} / \mathrm{min}$. The tissues were kept in a mixture of $95 \% \mathrm{O}_{2}$ and $5 \% \mathrm{CO}_{2}$. Synaptic plasticity in the CA1 area of the hippocampus at 6 weeks can be evaluated by high-frequency stimulation (HFS)induced increase in f-EPSP after LTP. The baseline level before HFS was measured for 10-15 min and allowed to stabilize. Input/output curves were obtained by increasing the intensity of the stimulus and adjusting it to elicit 70\% of the maximal response. The f-EPSP was recorded and the stimulus value corresponding to a 50\% amplitude difference was recorded as the HFS. The tissue was stimulated twice with HFS, and LTP was induced 10 s later

$$
\begin{array}{lr}
\text { http://www.endocrineconnections.org } & \text { O2018 The authors } \\
\text { https://doi.org/10.1530/EC-18-0069 } & \text { Published by Bioscientifica Ltd }
\end{array}
$$

and recorded for at least $30 \mathrm{~min}$. The percentage f-EPSP (f-EPSP\%) increased after HFS was used as an indicator to evaluate LTP.

\section{Western blotting}

On PND7, the pups were decapitated on ice. The cerebral cortex was removed immediately and $0.1 \mathrm{~g}$ cerebral cortex tissue was added to $200 \mu \mathrm{L}$ buffer containing protease and phosphatase inhibitors, homogenized by shaking (KeyGenBiotech, Nanjing, China) and centrifuged at $20,913 \boldsymbol{g}$ for $10 \mathrm{~min}$ at $4^{\circ} \mathrm{C}$. Protein concentrations were determined by the bicinchoninic acid method (Beyotime, Shanghai, China), and the samples were then stored at $-80^{\circ} \mathrm{C}$. Tissue lysates were diluted to the same protein concentrations $(5 \mu \mathrm{g} / \mu \mathrm{L})$, boiled for $8 \mathrm{~min}$ and $10 \mu \mathrm{L}$ (50g protein) samples from each group were then electrophoresed in 10\% SDS-polyacrylamide gels. The marker was separated at constant voltage of $80 \mathrm{~V}$ for 30-60 min, and the proteins were then separated at a constant voltage of $120 \mathrm{~V}$ for $1 \mathrm{~h}$. The proteins were then transferred to PVDF membranes (Millipore) at a constant voltage of $70 \mathrm{~V}$ for $2 \mathrm{~h}$. Non-specific binding was blocked using a mixture of skimmed milk powder with Trisbuffered saline and Tween 20 , with bovine serum albumin for $\mathrm{p}$-JNK. The membranes were then incubated for $4 \mathrm{~h}$ in the dark with the following antibodies: rabbit antip75 ${ }^{\text {NTR }}$ (1:1000 dilution; Cell Signaling Technologies); rabbit anti-total JNK (1:1000 dilution; Cell Signaling Technologies); rabbit anti-p-JNK (1:1000 dilution; Cell Signaling Technologies); rabbit anti-p53 (1:1000 dilution; Cell Signaling Technologies) and rabbit anti-Bax (1:1000 dilution; Cell Signaling Technologies). The blots were then incubated for $2 \mathrm{~h}$ with horseradish peroxidaseconjugated secondary antibody (1:10,000 dilution; Zhongshan Golden Bridge, Beijing, China) and developed by chemiluminescent Western blotting (ALPHAVIEW, version 1.3; ProteinSimple Inc., San Jose, CA, USA). The optimal time to expose the blot to the membrane was determined by standardization experiments.

\section{Statistical analysis}

Data processing and statistics were performed using SPSS 22.0 software (SPSS). The results were expressed as the mean \pm standard error of the mean (s.E.M.). Multiple group comparisons were performed using one-way ANOVA test followed by Dunnett's T3 test. Independent sample $t$ tests were used for comparisons between two groups. A value of $P<0.05$ was considered to be statistically significant. 


\section{Results}

\section{TH levels in pregnant rats}

We measured serum TT4 and TSH levels in pregnant rats to confirm successful establishment of the $\mathrm{SCH}$ and $\mathrm{OH}$ models. TSH levels were significantly higher in the $\mathrm{SCH}$ and $\mathrm{OH}$ groups compared with those in the $\mathrm{CON}$ group before pregnancy $(P<0.05)$. TT4 levels were the lowest in the $\mathrm{OH}$ group among the three groups $(P<0.05)$. And TT4 levels in the SCH group were significantly higher compared with those in the $\mathrm{OH}$ group $(P<0.05)$. However, there was no significant difference between the $\mathrm{SCH}$ group and the CON group $(P=0.755)$. On PND1, TSH levels in SCH group were higher than those in CON group, and TT4 levels were similar to those in CON group. These results indicated that the $\mathrm{SCH}$ models in rats were established successfully throughout the pregnancy (Fig. 2).
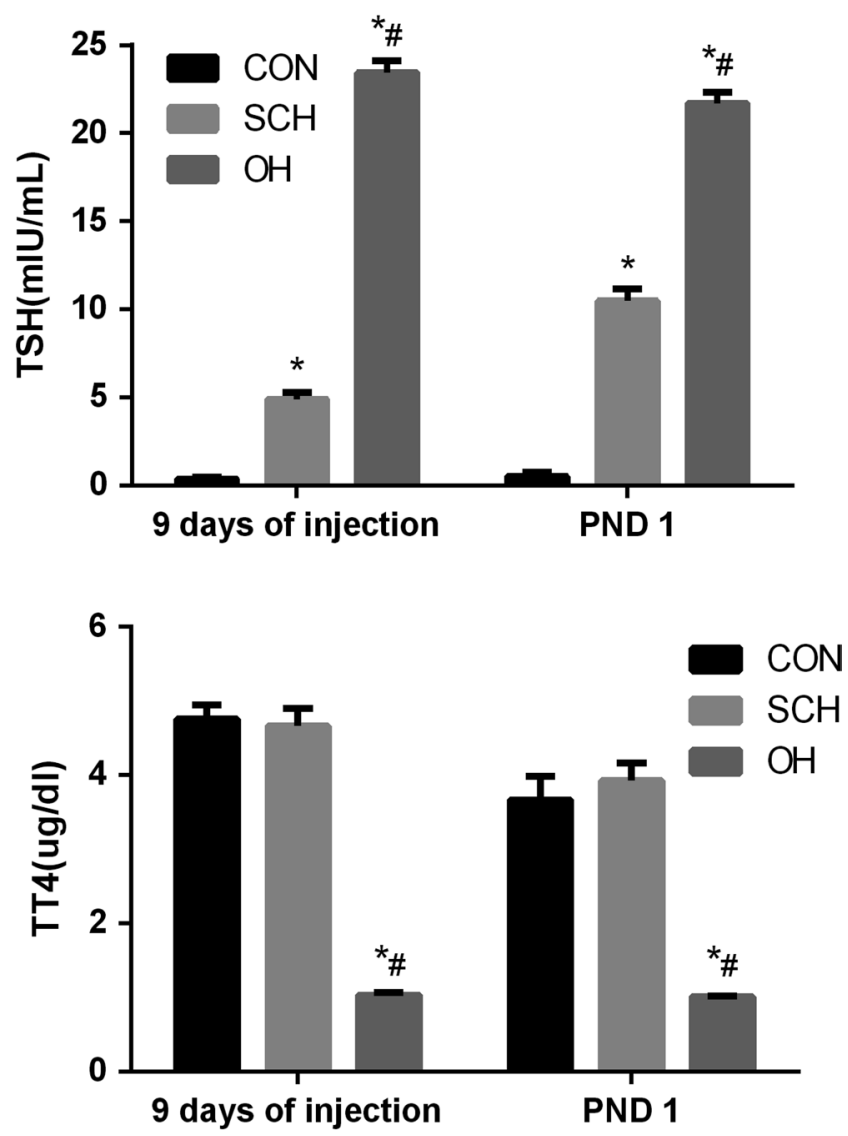

Figure 2

Thyroid-stimulating hormone (TSH) and serum total thyroxine (TT4) levels in pregnant rats ( 9 days of injection, $n=10$ per group; PND1, $n=6$ per group). ${ }^{*} P<0.05$ vs same day CON group; ${ }^{\#} P<0.05$ vs same day $\mathrm{SCH}$ group. $\mathrm{CON}$, control; $\mathrm{OH}$, overt hypothyroidism; PND 1, postnatal day $1 ; \mathrm{SCH}$, subclinical hypothyroidism; TSH, thyrotropin; TT4, total thyroxine.

$$
\text { http://www.endocrineconnections.org }
$$

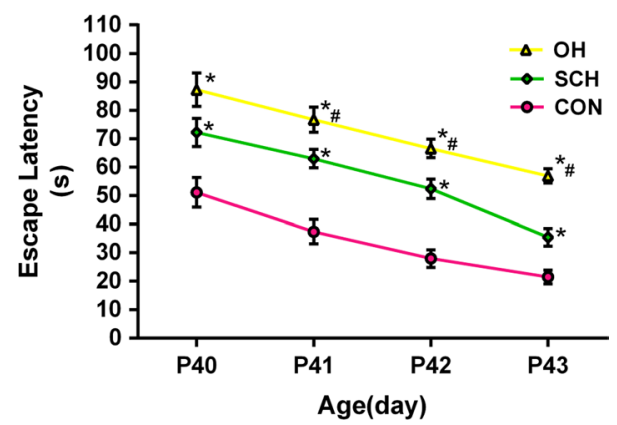

Figure 3

Performance of pups in the MWM test. Data are expressed as the mean \pm S.E.M. ( $n=10$ for each group). Average time to find the hidden platform was longer in the $\mathrm{SCH}$ and $\mathrm{OH}$ groups compared with the $\mathrm{CON}$ group from PND 40-43.

\section{Decline in learning and memory in offspring of rats with SCH during pregnancy}

We assessed spatial learning and memory in the offspring of rats with and without SCH using the MWM test. Escape latency decreased with increased training in all groups. Escape latency was significantly longer in the $\mathrm{SCH}$ group compared with the CON group, but escape latency was the longest in the $\mathrm{OH}$ group $(P<0.05$; Fig. 3). The time spent in the platform quadrant in the probe trial was $29.5 \pm 2.4 \mathrm{~s}$ in the CON group, $21.4 \pm 1.3 \mathrm{~s}$ in the $\mathrm{SCH}$ group and $17.6 \pm 0.5 \mathrm{~s}$ in the $\mathrm{OH}$ group (all $P<0.05$; Fig. 4). We also calculated the number of times that the pups crossed the platform quadrant, which was $7.98 \pm 0.37$ times in the CON group, $6.53 \pm 0.16$ times in the $\mathrm{SCH}$ group and $5.30 \pm 0.34$ times in the $\mathrm{OH}$ group (all $P<0.05$; Fig. 5). These results showed that spatial learning and memory reduced in the offspring of mothers with SCH during pregnancy.

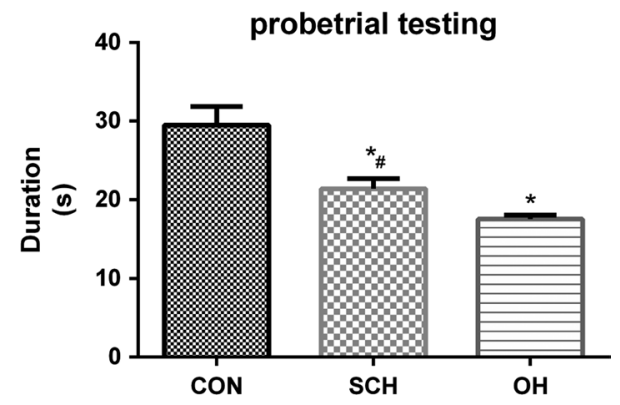

Figure 4

Probe trial test recorded the time spending by each pup in the platform area. Pups in the $\mathrm{SCH}$ and $\mathrm{OH}$ groups spent less times than pups in the CON group. ${ }^{*} P<0.05$ vs same day CON group; ${ }^{\sharp} P<0.05$ vs same day $\mathrm{OH}$ group.

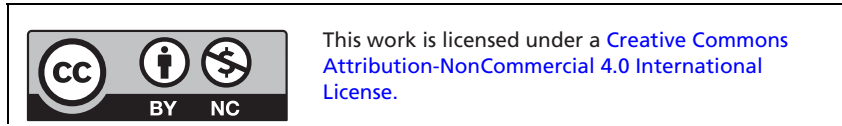




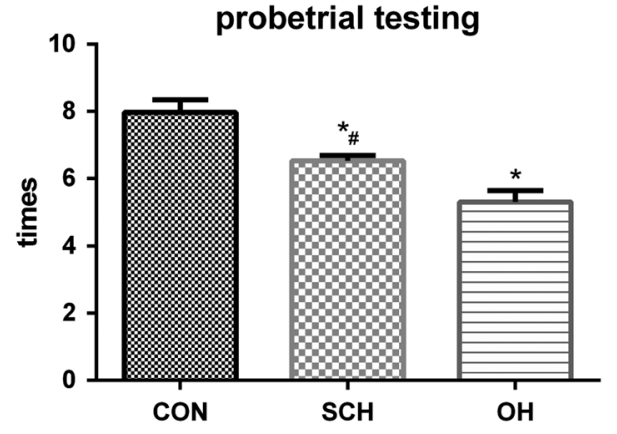

Figure 5

Probe trial test recorded the number of times pups crossed the platform quadrant. Pups in the $\mathrm{SCH}$ and $\mathrm{OH}$ groups crossed fewer times than pups in the CON group. ${ }^{*} P<0.05$ vs same day CON group; ${ }^{\#} P<0.05$ vs same day $\mathrm{OH}$ group.

\section{LTP in offspring of rats with SCH during pregnancy}

The LTP results were evaluated by measuring the percentage of baseline f-EPSP (f-EPSP\%) after HFS. There was no significant difference in f-EPSP among the three groups before HFS $(P>0.05)$; however, all three groups showed an increase in f-EPSP after HFS, with significant differences in the f-EPSP\% among the three groups. The f-EPSP $\%$ reduced in the SCH $(175 \pm 1 \%)$ and $\mathrm{OH}$ groups $(148 \pm 1 \%)$ compared with the CON group (209 $\pm 1 \%)$ $(n=6, P<0.05)$. However, the amplitude of the increase in the SCH group was significantly greater than that in the $\mathrm{OH}$ group $(P<0.05$; Fig. 6$)$. These results suggested that $\mathrm{SCH}$ during pregnancy could damage LTP in the offspring.

\section{Expression of the transcription factor $p 75^{\mathrm{NTR}}$ in offspring of rats with SCH during pregnancy}

We measured the expression levels of $\mathrm{p} 75^{\mathrm{NTR}}$ in the cerebral cortex of pups from mother rats in the three groups. p75 ${ }^{\text {NTR }}$ levels were significantly increased in the SCH and $\mathrm{OH}$ groups to 1.56-fold and 2.36-fold higher compared with those in the CON group, respectively $(n=6$, both $P<0.05)$. p75 ${ }^{\text {NTR }}$ levels in the $\mathrm{OH}$ group increased to 1.54 fold higher compared with levels in the SCH group $(n=6$, $P<0.05$; Fig. 7).

\section{JNK and p-JNK expression in offspring of rats with SCH during pregnancy}

p-JNK expression and activation were determined by Western blotting, and p-JNK and total JNK were identified by rabbit polyclonal antibodies. p-JNK levels increased significantly in the pups of SCH (1.47-fold) and OH group (1.93-fold) compared with those in the CON group $(n=6$, both $P<0.05$; Fig. 6). However, there was no significant difference in total JNK among the three groups.

\section{p53 expression in offspring of rats with $\mathrm{SCH}$ during pregnancy}

Hypothyroidism promotes $N$-methyl-D-aspartate receptor activation, which in turn increases p53 expression, probably by increasing DNA damage and

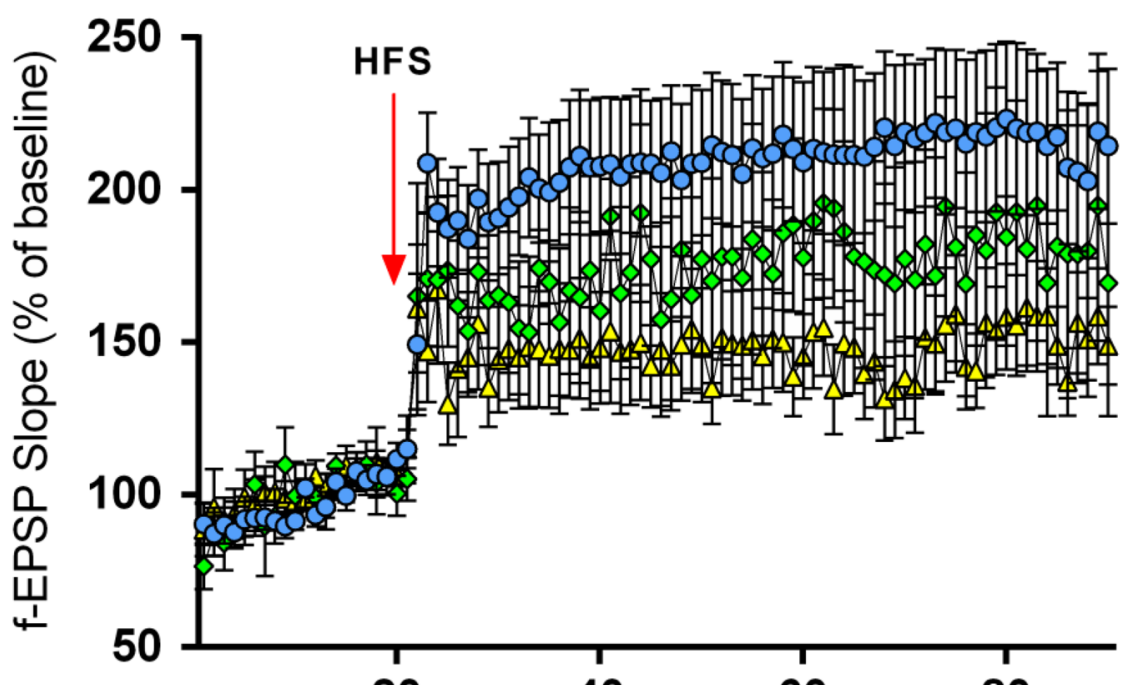

20
40

60
80

\section{Figure 6}

Maternal SCH caused LTP damage in the hippocampal CA1 region in their pups. LTP was induced by HFS and measured as an increase in $f$-EPSP slope, expressed as percent of the baseline of $f$-EPSP slope after HFS in different groups. $f$-EPSP slopes were reduced in the $\mathrm{SCH}$ and $\mathrm{OH}$ groups compared with the CON group $(P<0.05)$.
(O2018 The authors Published by Bioscientifica Ltd

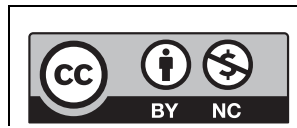

This work is licensed under a Creative Commons Attribution-NonCommercial 4.0 International License. 

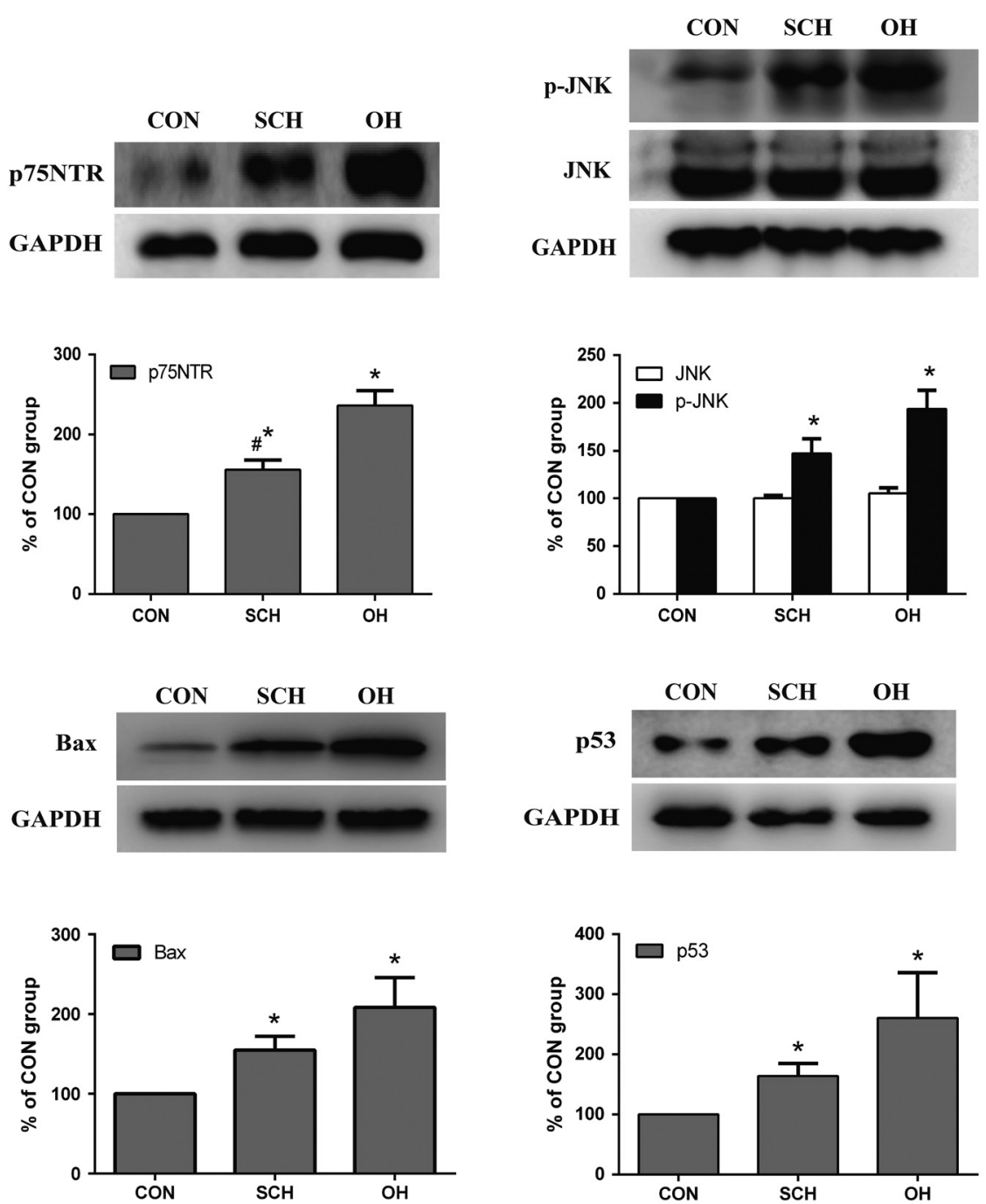

Figure 7

Protein expression levels of $\mathrm{p} 75$ neurotrophin receptor (p75 $\left.{ }^{\text {NTR }}\right)$, phospho-c-Jun N-terminal kinase ( $\mathrm{p}-\mathrm{JNK}$ ) and pro-apoptotic proteins $\mathrm{p} 53$ and Bax in the cortex of pups ( $n=6$ per group). ${ }^{*} P<0.05$ vs $\mathrm{CON}$ group, ${ }^{"} P<0.05$ vs $\mathrm{OH}$ group. triggers apoptosis leading to cell death (11). p53 is an important member of the p75 ${ }^{\mathrm{NTR}}$ signaling pathway, and it can induce cell apoptosis. We detected p53 and other components of the p75 ${ }^{\mathrm{NTR}}$ signaling pathway in this study. The expression levels of p53 increased significantly in the cerebral cortex of pups in the SCH (1.64-fold) and $\mathrm{OH}$ group (2.16-fold) compared with those in the CON group $(n=6$, both $P<0.05)$, as shown by Western blotting (Fig. 7).

\section{Bax expression in offspring of rats with $\mathrm{SCH}$ during pregnancy}

p53 can induce apoptosis by raising Bax levels, leading to caspase activation (12). Bax expression increased in pups from the $\mathrm{SCH}$ (1.55-fold) and $\mathrm{OH}$ group (2.08-fold) compared with those in the CON group ( $n=6, P<0.05$; Fig. 7$)$. These results were consistent with a previous report (9).

$\begin{array}{lr}\text { http://www.endocrineconnections.org } & \text { O2018 The authors } \\ \text { https://doi.org/10.1530/EC-18-0069 } & \text { Published by Bioscientifica Ltd }\end{array}$

\section{Discussion}

Epidemiological studies suggest that SCH during pregnancy may affect the offspring's intellectual development (1). Our group has performed a series of experiments to explore the mechanism in it (6). The current study explored the mechanism further from other aspect.

THs play a crucial role in fetal brain development and are involved in the proliferation, differentiation, maturation and migration of neurons in the brain. However, the fetal brain begins to develop before the thyroid, so THs needed for fetal brain development during early pregnancy are therefore derived exclusively from the mother. Moderate or even temporary hypothyroidism in early pregnancy may thus affect the normal migration of cortical neurons and the cellular architecture of the cerebral cortex and hippocampus (13). TH is also involved in apoptosis, which is another important physiological process in cerebral neuron development. Recent research

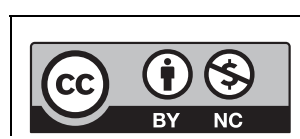

This work is licensed under a Creative Commons Attribution-NonCommercial 4.0 International License. 
reported that neonatal hypothyroidism could cause extensive apoptosis of granular cells in the cerebellum (14, $15,16,17)$, while maternal hypothyroidism could induce apoptosis in the fetal cortex (9). We therefore investigated if maternal perinatal SCH could also induce apoptosis in their offspring's cerebral cortex.

Experimental hypothyroidism in neonatal rats was associated with structural defects in the nervous system accompanied by behavioral abnormalities (18). Methimazole and iodine deficiency have traditionally been used to establish models of thyroid deficiency, but these could potentially have other effects on embryogenesis. Surgical removal of the thyroid gland, together with $\mathrm{TH}$ supplementation, is thus a preferable method for achieving SCH. We successfully established a surgical model of SCH by this method.

The previous study performed by our group has reported that offspring of rats with either $\mathrm{OH}$ or $\mathrm{SCH}$ had cognitive impairment (6). Spatial learning and memory, measured by MWM test, were significantly decreased in the $\mathrm{SCH}$ group compared with the CON group and were more severely affected in the $\mathrm{OH}$ compared with the $\mathrm{SCH}$ group. In addition, these differences became more apparent with more training sessions. The probe test also indicated sustained memory impairment in the $\mathrm{SCH}$ and $\mathrm{OH}$ groups compared with the CON group. These results suggest that the pups born to mothers with either $\mathrm{SCH}$ or $\mathrm{OH}$ developed irreversible neuronal damage, and the neural network connectivity could not be reconstructed even after prolonged training. This was consistent with previous findings $(6,19,20)$.

Hippocampal LTP is considered to be a suitable electrophysiological model for assessing synaptic plasticity in relation to learning and memory. The current results showed that prenatal exposure to $\mathrm{OH}$ and $\mathrm{SCH}$ led to a smaller increase in amplitude of f-EPSP after HFS, indicating LTP damage, consistent with previous studies $(6,19,21)$. This supports the hypothesis that both $\mathrm{OH}$ and SCH may cause LTP impairment.

Maternal hypothyroidism can increase neuronal apoptosis during brain development (9), and previous studies showed that hypothyroidism increased apoptosis in the cerebellum $(14,15,16,17)$ and hippocampus $(22,23)$. Maternal hypothyroidism during pregnancy can also increase apoptosis during cerebral cortex development in the pups, especially in the surface layer of the primary somatosensory cortex (I-III level), which mainly affects neurons (9).

$\mathrm{TH}$ modulates levels of nerve growth factor (NGF) in the cerebral cortex, hippocampus and cerebellum in rats

http://www.endocrineconnections.org https://doi.org/10.1530/EC-18-0069

C2018 The authors Published by Bioscientifica Ltd
$(14,24)$. Synaptic plasticity, neuronal excitability and cognitive function are all regulated by NGF, which also plays critical roles in regulating hippocampal plasticity and learning in rodents $(25,26,27,28)$. NGF regulates neuronal cell proliferation and apoptosis by binding to two different receptor tyrosine kinase receptors A (TrkA) and p75 ${ }^{\mathrm{NTR}}(29,30)$. When NGF levels decreases, the TrkA signal pathway is inhibited and the p75 pathway is activated (31), thereby affecting learningand memory-related protein expression, resulting in neuronal degeneration, apoptosis and mental retardation (32). ProNGF is a precursor protein of NGF and can induce apoptosis in many kinds of cells by combining

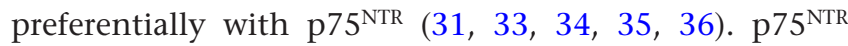
can also transmit signals independently to promote the apoptosis of a variety of cells, including developing neurons $(34,35)$. The current results showed that $\mathrm{p} 75^{\mathrm{NTR}}$ expression increased in the cerebral cortex of pups of hypothyroid rats, even in the case of $\mathrm{SCH}$, suggesting that elevated levels of maternal TSH may increase apoptosis in the cerebral cortex in their offspring.

Several models of $\mathrm{p} 75^{\mathrm{NTR}}$-dependent cell death have demonstrated the involvement JNK activity $(29,35,37,38$, $39,40,41)$. Increased $\mathrm{p} 75^{\mathrm{NTR}}$ has been reported to activate the JNK pathway, suggesting a link between JNK activation and cell death. Overexpression of the p75 ${ }^{\mathrm{NTR}}$ adaptor protein NRAGE was shown to induce apoptosis in a JNKdependent manner (37). JNK activation is also considered to be a molecular switch in stress signal transduction (42). Some stimuli, including cytokines (such as tumor necrosis factor and interleukin-1) and reactive oxygen species, can activate the JNK pathway and play an important role in regulating cell fate, including cell proliferation, gene expression and apoptosis (43). Sherrin et al. also reported a role for JNK in the hippocampus in terms of memory and synaptic plasticity (44). JNK expression in the hippocampus and cortex may thus influence learning and memory.

p75 ${ }^{\text {NTR }}$ can transduce a dichotomous signal with both pro-apoptotic and anti-apoptotic functions. The tumor suppressor p53 is a nuclear phospho-protein that can promote arrest or apoptosis, and it is an essential factor in JNK-mediated neuronal apoptosis. When DNA is damaged, p53 induces the expression of the cyclindependent kinase inhibitor p21, leading to cell cycle stagnation (45). Previous studies found that increased JNK activation was consistent with increased expression of the pro-apoptotic proteins p53 and Bax in hypothyroidism (10) (Fig. 8).

Activation of $\mathrm{p} 75^{\mathrm{NTR}}$, JNK and p53 signaling have also been associated with increased neuronal apoptosis in 


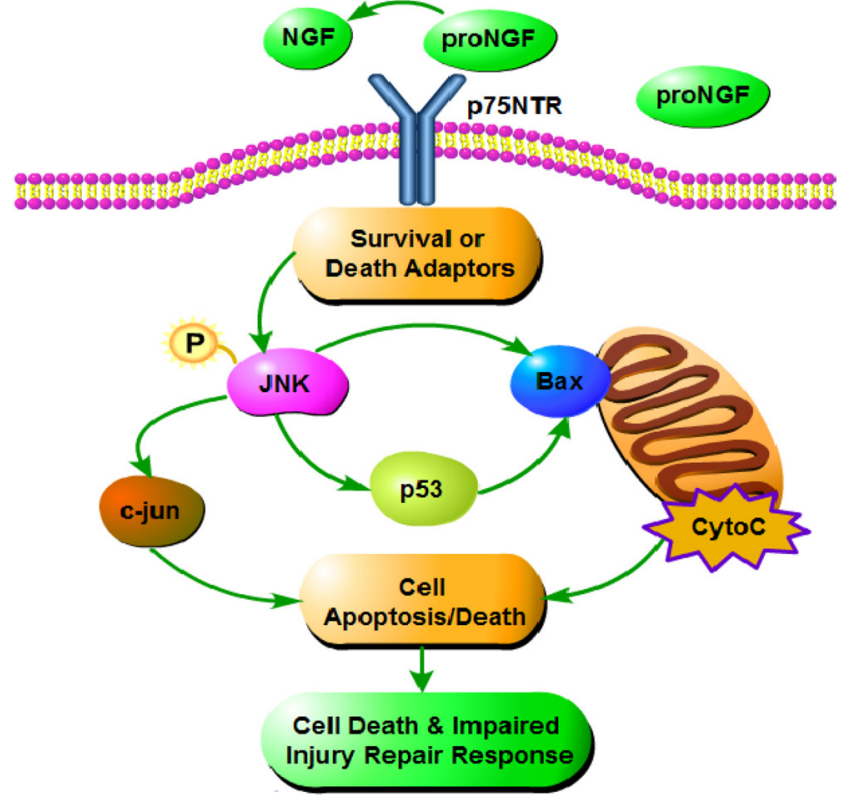

\section{Figure 8}

Effects of $\mathrm{SCH}$ and $\mathrm{OH}$ on $\mathrm{p} 75^{\mathrm{NTR}}$ signaling pathway. ProNGF, as a precursor protein of NGF, can combine with p75 ${ }^{\text {NTR }}$ preferentially. p75 NTR activates the JNK pathway to increase the $\mathrm{p} 53$ signaling pathway. $\mathrm{p} 53$ and Bax play essential roles in JNK-mediated neuronal apoptosis. In the present study, maternal $\mathrm{SCH}$ and $\mathrm{OH}$ increased $\mathrm{p} 75^{\mathrm{NTR}}$ expression in the offspring, thus increasing activation of p-JNK, Bax and p53 signaling pathways and thereby increasing neuronal apoptosis.

Alzheimer's disease (46). Our results suggest that similar changes in terms of increased apoptosis occurred in the cerebral cortex of pups exposed to perinatal SCH. This may explain the mechanism involved in the damage to the neurodevelopment of the offspring from SCH mothers partly. However, some other potential mechanisms may exist. Zhang et al. found decreased activation of the CREB signaling pathway in pups was related to impairments of cognitive function caused by maternal SCH (6). Lu et al. reported maternal SCH affects cytoarchitecture and cell migration in the developing brain of the progeny (47). A recent study of patients with Alzheimer's disease and SCH showed that regional cerebral blood flow was significantly reduced, suggesting that $\mathrm{SCH}$ may affect the perfusion of brain regions associated with memory function (48). This may provide a new direction for research into $\mathrm{SCH}$ induced memory deficits.

\section{Limitations}

Several limitations exist in our study. We did not perform Western blotting or other molecular biological experiments in the pups following MWM experiments, because we considered that the training may have affected the neurons in the cerebral cortex and thus affected spatial learning and memory. Furthermore, some rats died after thyroid surgery and some fetuses were aborted, which limited the availability of the cortical tissue for PCR, immunofluorescence, immunohistochemistry and other molecular experiments.

\section{Conclusions}

In summary, this study showed that perinatal SCH could increase the expression of p-JNK and the pro-apoptotic proteins p53 and Bax and increase neuronal apoptosis in the cerebral cortex of pups exposed to perinatal $\mathrm{SCH}$, by activating the $\mathrm{p} 75^{\mathrm{NTR}}$ signaling pathway. These results help to explain the cellular mechanisms whereby maternal SCH during pregnancy may adversely affect the development of the offspring's cerebral cortex.

\section{Declaration of interest}

The authors declare that there is no conflict of interest that could be perceived as prejudicing the impartiality of the research reported.

\section{Funding}

This study was supported by the Chinese National Natural Science Foundation (grant: 81500605) and the National Science and Technology Support Program (grant: 2014BAI06B02). The funder had no role in study design, data collection or analysis or in the presentation or publication of the results.

\section{References}

1 Haddow JE, Palomaki GE, Allan WC, Williams JR, Knight GJ, Gagnon J, O'Heir CE, Mitchell ML, Hermos RJ, Waisbren SE, et al. Maternal thyroid deficiency during pregnancy and subsequent neuropsychological development of the child. New England Journal of Medicine 1999341 549-555. (https://doi.org/10.1056/ NEJM199908193410801)

2 Anderson GW, Schoonover CM \& Jones SA. Control of thyroid hormone action in the developing rat brain. Thyroid $2003 \mathbf{1 3}$ 1039-1056. (https://doi.org/10.1089/105072503770867219)

3 Bernal J, Guadano-Ferraz A \& Morte B. Perspectives in the study of thyroid hormone action on brain development and function. Thyroid 200313 1005-1012. (https://doi.org/10.1089/105072503770867174)

4 Mastorakos G, Karoutsou EI, Mizamtsidi M \& Creatsas G. The menace of endocrine disruptors on thyroid hormone physiology and their impact on intrauterine development. Endocrine 200731 219-237. (https://doi.org/10.1007/s12020-007-0030-y)

5 Zoeller RT \& Rovet J. Timing of thyroid hormone action in the developing brain: clinical observations and experimental findings. Journal of Neuroendocrinology 200416 809-818. (https://doi. org/10.1111/j.1365-2826.2004.01243.x)

6 Zhang Y, Fan Y, Yu X, Wang X, Bao S, Li J, Fan C, Shan Z \& Teng W. Maternal subclinical hypothyroidism impairs neurodevelopment in rat offspring by inhibiting the CREB signaling pathway. Molecular http://www.endocrineconnections.org

https://doi.org/10.1530/EC-18-0069
@2018 The authors Published by Bioscientifica Ltd
This work is licensed under a Creative Commons Attribution-NonCommercial 4.0 International License. 
Neurobiology 201552 432-441. (https://doi.org/10.1007/s12035-0148855-x)

7 Hempstead BL. The many faces of p75NTR. Current Opinion in Neurobiology 200212 260-267. (https://doi.org/10.1016/S09594388(02)00321-5)

8 Roux PP \& Barker PA. Neurotrophin signaling through the p75 neurotrophin receptor. Progress in Neurobiology $200267203-233$ (https://doi.org/10.1016/S0301-0082(02)00016-3)

9 Kumar A, Sinha RA, Tiwari M, Pal L, Shrivastava A, Singh R, Kumar K, Kumar Gupta S \& Godbole MM. Increased pro-nerve growth factor and p75 neurotrophin receptor levels in developing hypothyroid rat cerebral cortex are associated with enhanced apoptosis. Endocrinology 2006147 4893-4903. (https://doi.org/10.1210/en.2006-0027)

10 Sinha RA, Pathak A, Kumar A, Tiwari M, Shrivastava A \& Godbole MM. Enhanced neuronal loss under perinatal hypothyroidism involves impaired neurotrophic signaling and increased proteolysis of p75(NTR). Molecular and Cellular Neurosciences 200940 354-364. (https://doi.org/10.1016/j.mcn.2008.12.001)

11 Alva-Sanchez C, Rodriguez A, Villanueva I, Anguiano B, Aceves C \& Pacheco-Rosado J. The NMDA receptor antagonist MK-801 abolishes the increase in both $\mathrm{p} 53$ and $\mathrm{Bax} / \mathrm{Bcl} 2$ index induced by adult-onset hypothyroidism in rat. Acta Neurobiologiae Experimentalis $2014 \mathbf{7 4}$ 111-117.

12 Miller FD, Pozniak CD \& Walsh GS. Neuronal life and death: an essential role for the p53 family. Cell Death and Differentiation 20007 880-888. (https://doi.org/10.1038/sj.cdd.4400736)

13 Auso E, Lavado-Autric R, Cuevas E, Del Rey FE, Morreale De Escobar G \& Berbel P. A moderate and transient deficiency of maternal thyroid function at the beginning of fetal neocorticogenesis alters neuronal migration. Endocrinology 2004145 4037-4047. (https://doi.org/10.1210/en.2004-0274)

14 Neveu I \& Arenas E. Neurotrophins promote the survival and development of neurons in the cerebellum of hypothyroid rats in vivo. Journal of Cell Biology 1996133 631-646. (https://doi. org/10.1083/jcb.133.3.631)

15 Singh R, Upadhyay G \& Godbole MM. Hypothyroidism alters mitochondrial morphology and induces release of apoptogenic proteins during rat cerebellar development. Journal of Endocrinology 2003176 321-329. (https://doi.org/10.1677/joe.0.1760321)

16 Singh R, Upadhyay G, Kumar S, Kapoor A, Kumar A, Tiwari M \& Godbole MM. Hypothyroidism alters the expression of Bcl-2 family genes to induce enhanced apoptosis in the developing cerebellum. Journal of Endocrinology $2003 \mathbf{1 7 6} 39-46$.

17 Xiao Q \& Nikodem VM. Apoptosis in the developing cerebellum of the thyroid hormone deficient rat. Frontiers in Bioscience 19983 A52-A57. (https://doi.org/10.2741/A252)

18 Cragg BG. Synapses and membranous bodies in experimental hypothyroidism. Brain Research 197018 297-307. (https://doi. org/10.1016/0006-8993(70)90330-6)

19 Wang Y, Wei W, Wang Y, Dong J, Song B, Min H, Teng W \& Chen J. Neurotoxicity of developmental hypothyroxinemia and hypothyroidism in rats: impairments of long-term potentiation are mediated by phosphatidylinositol 3-kinase signaling pathway. Toxicology and Applied Pharmacology 2013271 257-265. (https://doi. org/10.1016/j.taap.2013.04.034)

20 Dong J, Liu W, Wang Y, Hou Y, Xu H, Gong J, Xi Q \& Chen J. Developmental iodine deficiency and hypothyroidism impair spatial memory in adolescent rat hippocampus: involvement of CaMKII, calmodulin and calcineurin. Neurotoxicity Research 201119 81-93. (https://doi.org/10.1007/s12640-009-9142-x)

21 Kandel ER. The molecular biology of memory storage: a dialogue between genes and synapses. Science 2001294 1030-1038. (https:// doi.org/10.1126/science.1067020)

22 Huang XW, Zhao ZY \& Ji C. Effects of hypothyroidism on apoptosis and the expression of Bcl-2 and Bax gene in the neonatal rat hippocampus neurons. Zhonghua Er Ke Za Zhi 200543 48-52.
23 Huang XW, Yang RL, Zhao ZY, Ji C \& Yang RW. Mechanism for apoptosis of hippocampus neuron induced by hypothyroidism in perinatal rats. Zhejiang Da Xue Xue Bao Yi Xue Ban 200534 298-303.

24 Alvarez-Dolado M, Iglesias T, Rodriguez-Pena A, Bernal J \& Munoz A. Expression of neurotrophins and the trk family of neurotrophin receptors in normal and hypothyroid rat brain. Brain Research Molecular Brain Research 199427 249-257. (https://doi. org/10.1016/0169-328X(94)90007-8)

25 Sola E, Capsoni S, Rosato-Siri M, Cattaneo A \& Cherubini E. Failure of nicotine-dependent enhancement of synaptic efficacy at Schaffercollateral CA1 synapses of AD11 anti-nerve growth factor transgenic mice. European Journal of Neuroscience 200624 1252-1264. (https:// doi.org/10.1111/j.1460-9568.2006.04996.x)

26 Rosato-Siri M, Cattaneo A \& Cherubini E. Nicotine-induced enhancement of synaptic plasticity at CA3-CA1 synapses requires GABAergic interneurons in adult anti-NGF mice. Journal of Physiology 2006576 361-377. (https://doi.org/10.1113/jphysiol.2006.114587)

27 Lagostena L, Rosato-Siri M, D’Onofrio M, Brandi R, Arisi I, Capsoni S, Franzot J, Cattaneo A \& Cherubini E. In the adult hippocampus, chronic nerve growth factor deprivation shifts GABAergic signaling from the hyperpolarizing to the depolarizing direction. Journal of Neuroscience 201030 885-893. (https://doi.org/10.1523/ JNEUROSCI.3326-09.2010)

28 Conner JM, Franks KM, Titterness AK, Russell K, Merrill DA, Christie BR, Sejnowski TJ \& Tuszynski MH. NGF is essential for hippocampal plasticity and learning. Journal of Neuroscience 200929 10883-10889. (https://doi.org/10.1523/JNEUROSCI.2594-09.2009)

29 Yoon SO, Casaccia-Bonnefil P, Carter B \& Chao MV. Competitive signaling between TrkA and p75 nerve growth factor receptors determines cell survival. Journal of Neuroscience 199818 3273-3281. (https://doi.org/10.1523/JNEUROSCI.18-09-03273.1998)

30 Nykjaer A, Willnow TE \& Petersen CM. p75NTR--live or let die. Current Opinion in Neurobiology 200515 49-57. (https://doi. org/10.1016/j.conb.2005.01.004)

31 Fortress AM, Buhusi M, Helke KL \& Granholm AC. Cholinergic degeneration and alterations in the TrkA and p75NTR balance as a result of Pro-NGF injection into aged rats. Journal of Aging Research 20112011 460543. (https://doi.org/10.4061/2011/460543)

32 Capsoni S, Brandi R, Arisi I, D’Onofrio M \& Cattaneo A. A dual mechanism linking NGF/proNGF imbalance and early inflammation to Alzheimer's disease neurodegeneration in the AD11 anti-NGF mouse model. CNS and Neurological Disorders Drug Targets 201110 635-647.

33 Rabizadeh S, Oh J, Zhong LT, Yang J, Bitler CM, Butcher LL \& Bredesen DE. Induction of apoptosis by the low-affinity NGF receptor. Science 1993261 345-348. (https://doi.org/10.1126/ science.8332899)

34 Frade JM, Rodriguez-Tebar A \& Barde YA. Induction of cell death by endogenous nerve growth factor through its p75 receptor. Nature 1996383 166-168. (https://doi.org/10.1038/383166a0)

35 Casaccia-Bonnefil P, Carter BD, Dobrowsky RT \& Chao MV. Death of oligodendrocytes mediated by the interaction of nerve growth factor with its receptor p75. Nature 1996383 716-719. (https://doi. org/10.1038/383716a0)

36 Barrett GL \& Bartlett PF. The p75 nerve growth factor receptor mediates survival or death depending on the stage of sensory neuron development. PNAS 199491 6501-6505. (https://doi.org/10.1073/ pnas.91.14.6501)

37 Salehi AH, Xanthoudakis S \& Barker PA. NRAGE, a p75 neurotrophin receptor-interacting protein, induces caspase activation and cell death through a JNK-dependent mitochondrial pathway. Journal of Biological Chemistry 2002277 48043-48050. (https://doi. org/10.1074/jbc.M205324200)

38 Harrington AW, Kim JY \& Yoon SO. Activation of Rac GTPase by p75 is necessary for c-jun N-terminal kinase-mediated apoptosis. Journal of Neuroscience 200222 156-166. (https://doi.org/10.1523/ JNEUROSCI.22-01-00156.2002)

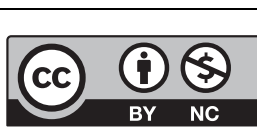

This work is licensed under a Creative Commons Attribution-NonCommercial 4.0 International License. 
39 Friedman WJ. Neurotrophins induce death of hippocampal neurons via the p75 receptor. Journal of Neuroscience 200020 6340-6346. (https://doi.org/10.1523/ JNEUROSCI.20-17-06340.2000)

40 Brann AB, Tcherpakov M, Williams IM, Futerman AH \& Fainzilber M. Nerve growth factor-induced p75-mediated death of cultured hippocampal neurons is age-dependent and transduced through ceramide generated by neutral sphingomyelinase. Journal of Biological Chemistry 2002277 9812-9818. (https://doi.org/10.1074/jbc. M109862200)

41 Aloyz RS, Bamji SX, Pozniak CD, Toma JG, Atwal J, Kaplan DR $\&$ Miller FD. p53 is essential for developmental neuron death as regulated by the TrkA and p75 neurotrophin receptors. Journal of Cell Biology 1998143 1691-1703. (https://doi.org/10.1083/ jcb.143.6.1691)

42 Cattani D, Goulart PB, Cavalli VL, Winkelmann-Duarte E, Dos Santos AQ, Pierozan P, de Souza DF, Woehl VM, Fernandes MC, Silva FR, et al. Congenital hypothyroidism alters the oxidative status, enzyme activities and morphological parameters in the hippocampus of developing rats. Molecular and Cellular Endocrinology 2013375 14-26. (https://doi.org/10.1016/j. mce.2013.05.001)

43 Seki E, Brenner DA \& Karin M. A liver full of JNK: signaling in regulation of cell function and disease pathogenesis, and clinical approaches. Gastroenterology 2012143 307-320. (https://doi. org/10.1053/j.gastro.2012.06.004)

44 Sherrin T, Blank T \& Todorovic C. c-Jun N-terminal kinases in memory and synaptic plasticity. Reviews in the Neurosciences 201122 403-410. (https://doi.org/10.1515/RNS.2011.032)

45 Golias CH, Charalabopoulos A \& Charalabopoulos K. Cell proliferation and cell cycle control: a mini review. International Journal of Clinical Practice 200458 1134-1141. (https://doi. org/10.1111/j.1742-1241.2004.00284.x)

46 Costantini C, Rossi F, Formaggio E, Bernardoni R, Cecconi D \& DellaBianca V. Characterization of the signaling pathway downstream p75 neurotrophin receptor involved in beta-amyloid peptide-dependent cell death. Journal of Molecular Neuroscience 200525 141-156. (https://doi.org/10.1385/JMN:25:2:141)

47 Lu L, Yu X, Teng W \& Shan Z. Treatment with levothyroxine in pregnant rats with subclinical hypothyroidism improves cell migration in the developing brain of the progeny. Journal of Endocrinological Investigation 201235 490-496. (https://doi. org/10.3275/7967)

48 Haji M, Kimura N, Hanaoka T, Aso Y, Takemaru M, Hirano T \& Matsubara E. Evaluation of regional cerebral blood flow in Alzheimer's disease patients with subclinical hypothyroidism. Dementia and Geriatric Cognitive Disorders 201539 360-367. (https:// doi.org/10.1159/000375298)

Received in final form 10 April 2018

Accepted 18 April 2018

Accepted Preprint published online 18 April 2018 http://www.endocrineconnections.org

https://doi.org/10.1530/EC-18-0069
(2)18 The authors Published by Bioscientifica Ltd

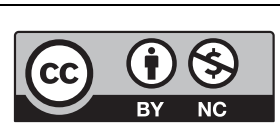

This work is licensed under a Creative Commons Attribution-NonCommercial 4.0 International License. 